\title{
Genomic selection in dairy cattle simulated populations
}

\author{
Leonardo de Oliveira Seno ${ }^{1}$, Diego Gomes Freire Guidolin ${ }^{2}$, Rusbel Raul Aspilcueta-Borquis ${ }^{1}$, \\ Guilherme Batista do Nascimento ${ }^{3}$, Thiago Bruno Ribeiro da Silva ${ }^{4}$, Henrique Nunes de Oliveira ${ }^{3}$ \\ and Danísio Prado Munari ${ }^{3}$
}

\author{
1 Grande Dourados Federal University (UFGD) - Dourados, MS, Brazil \\ ${ }^{2}$ Universidade Anhanguera (Uniderp) - Campo Grande, MS, Brazil \\ ${ }^{3}$ Universidade Estadual Paulista (UNESP) - Jaboticabal, SP, Brazil \\ ${ }^{4}$ Mato Grosso Federal University (UFMT) - Rondonópolis, MT, Brazil
}

Received 8 May 2017; accepted for publication 5 April 2018

Genomic selection is arguably the most promising tool for improving genetic gain in domestic animals to emerge in the last few decades, but is an expensive process. The aim of this study was to evaluate the economic impact related to the implementation of genomic selection in a simulated dairy cattle population. The software QMSim was used to simulate genomic and phenotypic data. The simulated genome contained 30 chromosomes with $100 \mathrm{~cm}$ each, 1666 SNPs markers equally spread and 266 QTLs randomly designated for each chromosome. The numbers of markers and QTLs were designated according to information available from Animal QTL (http://www.animalgenome.org/QTLdb) and Bovine QTL (http://bovineqtl.tamu.edu/). The allelic frequency changes were assigned in a gamma distribution with alpha parameters equal to $0 \cdot 4$. Recurrent mutation rates of $1 \cdot 0 \mathrm{e}^{-4}$ were assumed to apply to markers and QTLs. A historic population of 1000 individuals was generated and the total number of animals was reduced gradually along 850 generations until we obtained a number of 200 animals in the last generation, characterizing a bottleneck effect. Progenies were created along generations from random mating of the male and female gametes, assuming the same proportion of both genders. Than the population was extended for another 150 generations until we obtained 17000 animals, with only 320 male individuals in the last generation. After this period a 25 year of selection was simulated taking into account a trait limited by sex with heritability of 0.30 (i.e. milk yield), one progeny/cow/year and variance equal to $1 \cdot 0$. Annually, 320 bulls were mated with 16000 dams, assuming a replacement rate of 60 and $40 \%$ for males and females, respectively. Selection and discard criteria were based in four strategies to obtain the EBVs assuming as breeding objective to maximize milk yield. The progeny replaced the discarded animals creating an overlapping generation structure. The selection strategies were: RS is selection based on random values; PS is selection based on phenotypic values; Blup is selection based on EBVs estimated by BLUP; and GEBV is selection based on genomic estimated breeding values in one step, using high (GBlup) and low (GBlupi) density panels. Results indicated that the genetic evaluation using the aid of genomic information could provide better genetic gain rates in dairy cattle breeding programs as well as reduce the average inbreeding coefficient in the population. The economic viability indicators showed that only Blup and GBlup/GBlupi strategies, the ones that used milk control and genetic evaluation were economic viable, considering a discount rate of $6 \cdot 32 \%$ per year.

Keywords: Cost-benefit analysis, genetic parameters, single nucleotide polymorphisms.

After the implementation of molecular genetics in animal breeding, conventional selection strategies became more efficient, promoting greater genetic gain in traits of

*For correspondence; e-mail: leonardoseno@ufgd.edu.br economic interest (VanRaden et al. 2009). Genetic values estimation based on DNA markers information (GEBV 'Genomic Estimated Breeding Value') has been used in breeding programs around the world (De Roos et al. 2007; Harris et al. 2008; Hayes et al. 2009; VanRaden et al. 2009; Garrick, 2011), and provides greater selection accuracy and faster genetic gain when compared to conventional 
selection, which is based only in phenotypic data from an individual, its relatives and relationship information among individuals (Resende et al. 2008).

Schaeffer (2006) showed that in dairy cattle genomic selection could increase genetic gain approximately three times, reducing significantly the progeny test costs. This strategy can reduce the number of sires tested and aid the selection of young bulls, without information from their progeny, which leads to a smaller generation interval. In practice, is extremely hard to genotype all animas, so those methods should be adapted to this reality (Christensen \& Lund, 2010).

Young animals GEBV accuracy increases according to the number of animals included in the reference population used to estimate SNPs effects (Hayes et al. 2009). Increasing this reference population with others genotyped animals would increase genomic selection costs. Although adding non-genotyped animals, for which genotypes can be predicted, is a less expensive way to increase GEBVs accuracy (Pszczola et al. 2011).

Gengler et al. (2007) proposed a method that treated all genotypes as phenotypes and used the additive relationship matrix based on pedigree information to predict genotypes. Using parents, grandparents or any other relative genotypes information would allow imputing those non-genotyped animals.

For that, the following questions should be discussed: What are the effects of implementing genetic selection over genetic gain for an economic interest trait? What would be the effects of this biotechnology over endogamy coefficient? Which would be the economic benefits of its application? Simulation programs are being used to solve these questions, because they allow one to previously evaluate the adoption of a new tool to production and market scenarios of a given region or country. The objective of this study was to evaluate the cost-benefit relation, as well, to estimate genetic values and direct genomic values in a dairy cattle simulated population, as a result of different selection strategies considering production circumstances and market in the Southeast Region of Brazil.

\section{Materials and methods}

The QMsim software (Sargolzaei \& Schenkel, 2009) was used to simulate a historical population and recent population structure. Genome was simulated with 30 chromosomes with $100 \mathrm{~cm}$ each, with 1666 SNPs markers spaced uniformly and 264 QTLs designed randomly for each chromosome. The marker number and QTLs were designed according to information available on the data bases: Animal QTL (http://www.animalgenome.org/QTLdb) and Bovine QTL (http://bovineqtl.tamu.edu/). Changes in allele frequency through recent population were attributed to gamma distribution with alfa parameter equal to 0.4 as presented by Hayes \& Goddard (2001). Recurrent mutation rates were assumed only in historical population generations at a rate of $1.0 \times 10^{-4}$ for markers and QTLs.

To compose the historical population were generated 1000 individuals and through 850 generations the total individuals were gradually being reduced until reach 200 individuals in the last generation, characterizing a genetic bottleneck. Throughout generations, the progeny were generated from the random union of male and female gametes with the same sexual proportion. Following, the population was expanded for more 150 generations until reach 17000 animals, with 320 males in the last generation. This procedure aimed to produce a realistic linkage disequilibrium (LD) level, similar to the one found by Sargolzaei et al. (2008) in Canadian Holstein animals.

A 25 years selection horizon, considering a sex limited trait (e.g.: milk yield) with a heritability of $0 \cdot 30$, a progeny/ cow/year and a variance equal to $1 \cdot 0$, was simulated. Annually 320 sires were mated randomly with 16000 dams, it was considered a $60 \%$ and a $40 \%$ reposition rate, respectively, to produce 16000 progeny with a sexual proportion of $0 \cdot 5$.

Selection criteria and discard were based in four different strategies to obtain EBVs, being the objective to maximize milk production. Progeny replaced discarded animals creating a generation overlap. Strategies involved:

RS) selection based on random values, in which the genetic value of animal $i,\left(\hat{\mathrm{a}}_{\mathrm{i}}\right)$, was generated from an $\mathrm{N}$ distribution $(0 \cdot 1)$;

PS) Selection based on phenotypes values, in which were assumed as â(s):

a) The individual average, from cow's phenotypic data

b) Phenotypic average of the dam, for young animals (sires or dams); and

c) Daughters average, for sires;

Blup) Selection based on estimated breeding values using traditional selection, in which the $\mathrm{a}(\mathrm{s})$ of animals were obtained by the means of the restricted maximum likelihood method applied to an animal model; and

Selection based on Blup from the $1^{\text {st }}$ to $9^{\text {th }}$ year, together $\left(10^{\text {th }}\right.$ to $\left.25^{\text {th }}\right)$ with the adoption of a one-step prediction from high (GBlup) and low (Gblupi) density panels, as related by Misztal et al. (2009) and Aguilar et al. (2010), in which the relatedness is based on pedigree is adjusted by the deviations due to genomic information to predict the genotyped and non-genotyped animals â(s) (Legarra et al. 2009). It is important to make it clear that the genetics progress results were considered the same for GBlup and GBlupi, varying only the genotyping costs. Chud et al. (2015) described that low density panels $(50 \mathrm{~K})$ are fitted for genotype imputation in HD presenting acceptable precision, reduce genotyping costs and assist genomic selection evaluations.

As a genotyping strategy it was chosen to genotype all sires (320) on $10^{\text {th }}$ and following years, hired sires (192/ year) were genotyped, reaching a total of 3008 genotyped bulls. At the beginning due the low number of available 
sires, a genomic evaluating was appropriate, because of that it was decided to include 1000 females annually to compose the reference population, getting a total of 15 000 females. To choose the genotyping candidates the strategy adopted was to pick extreme phenotypes (minimum and maximum) as suggested by Jiménez-Montero et al. (2012) and Boligon et al. (2012).

An extra program, built in Fortran 90 was used to read phenotypic and genotypic information (when necessary) that were in temporary files created by QMSim. Next, phenotypic, genotypic and genomic random values obtained according the strategies used were read on QMSim, and based on that information selected the animals that would sire the next generation.

Revenues and costs calculation related to the application of different selection strategies were performed using

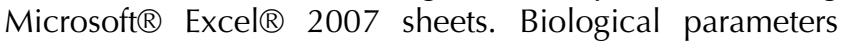
released by a local breeding program and entrance QMSim parameters data were used to define the herd composition/evolution, aiming to imitate the circumstances of a production system in the Southeast Region of Brazil (Table 1). Most herds in this region are considered small to medium and Holstein cows are kept in free stall systems. To make it more realistic, it was used the structure described by Barbosa Silveira et al. (2011) for a herd with 100 confined lactating cows, all products prices were retaken and the revenues and costs components were extrapolated for our population structure.

Table 1. Biological parameters assumed

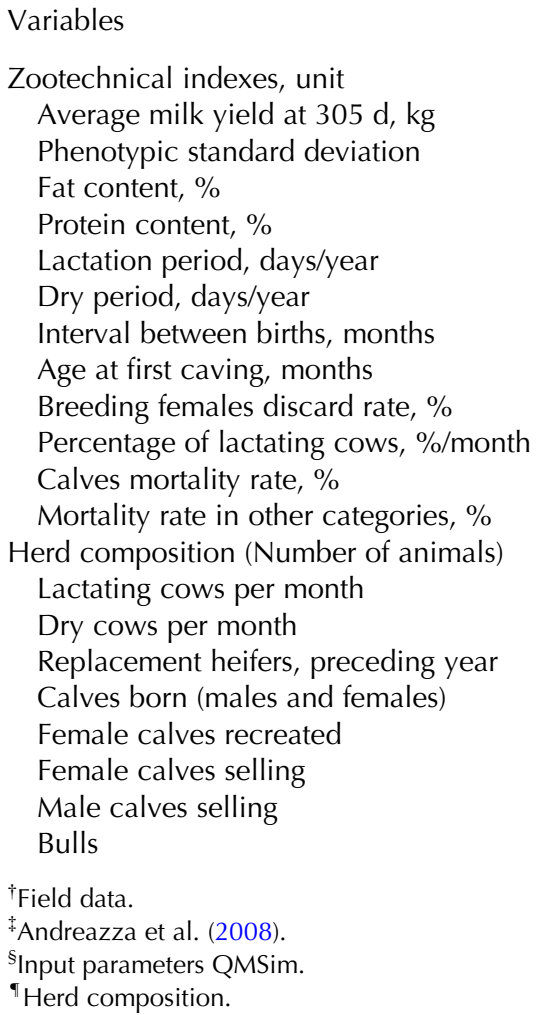

Value

$4350 \cdot 00^{\dagger}$ $1032 \cdot 00^{*}$ $4 \cdot 04^{\dagger}$ $3 \cdot 38^{\dagger}$ $305^{\dagger}$ $150^{\dagger}$ $15^{\dagger}$ $26^{\dagger}$

$40^{\S}$

$85^{\dagger}$

$5 \cdot 0^{\dagger}$

$3 \cdot 0^{\dagger}$

13328 "

$2352^{\pi}$

$6400^{\pi}$

$15680^{9}$

$7062^{\pi}$

$386^{\pi}$

$7448^{\pi}$

$320^{\S}$
All costs and revenues coming from the change in genetic merit were considered using the prices based on the year 2013, expressed in American Dollars (US\$). Products prices and production components (Table 2) were obtained in national reports of specialized economic statistics (ANUALPEC, 2013; IEA, 2013), when not available in literature, prices were obtained in companies and local farms.

Costs from pasture formation and maintenance as well as corn silage production were calculated based on costs sheets presented on ANUALPEC (2013). For the purpose to compare different strategies, artificial insemination (AI), dairy control with genetic evaluation, genotyping and additional feeding costs were considered as variable costs.

On RS strategy there were not considered costs associated to dairy control, genetic evaluation and genotyping. Dairy control costs were just considered starting on strategy PS and it was composed by the technicians charge per day, being equal to $25 \%$ of the minimum salary used in Brazil; mileage, which corresponded to $35 \%$ of a liter of gas; and average distance covered to realize dairy control, equivalent to $150 \mathrm{~km}$ (Cardoso et al. 2005).

Expenses related to genetic evaluation were considered on Blup, GBlup and GBlupi strategies (Table 2), for these last two it was also computed animal genotyping costs. It

Table 2. Average prices of the production components assumed in this study

Components, unit

Price (US\$)

Revenue

Milk, L

Discard cows, @

$0 \cdot 47^{\dagger}$

Heifers, animal

$43 \cdot 84^{\dagger}$

Female calves, animal

$1630 \cdot 52^{\ddagger}$

Male calves, animal

$698 \cdot 80^{*}$

Costs

Feeding

Silage, DM kg

P. maximum Jacq. cv. Colonião, DM kg

Concentrate, DM kg

$58 \cdot 23^{*}$

Mineral salt, kg

Urea, kg

Zootechnical control and genetic evaluation

Dairy control, animal/month

Daily, 25\% minimum wage,

Mileage, 35\% gasoline

Genetic evaluation, animal/month

$0 \cdot 03^{\S}$

$0 \cdot 01^{\S}$

$0 \cdot 69^{\dagger}$

$0 \cdot 78^{\dagger}$

$1 \cdot 10^{\dagger}$

Genotyping

BovineSNP50 BeadChip, animal

BovineLD BeadChip (6 K), animal

$1 \cdot 22^{\pi}$

$78 \cdot 56^{\dagger}$

$0 \cdot 45^{\dagger}$

$0.90^{\dagger \dagger}$

DM, dry matter.

'IEA (2013).

${ }^{\dagger}$ Field data.

${ }^{\S}$ ANUALPEC (2013).

"Dairy Herd Analysis Program of Paraná (APCBRH/UFPR 2013).

${ }^{\dagger}$ Gestor Leite (2013).

Heoxi (2013).

Exchange rate: $U S \$ 1 \cdot 00=R \$ 2 \cdot 16 \quad(2012-2013)$, minimum wage $=$ US $\$ 314 \cdot 23$. 
was assumed the utilization of a BovineSNP50v2 BeadChip panel for GBlup and it was considered animals' genotyping on the 10th year of evaluation for GBlupi (first year of genomic selection) using a BovineSNP50v2 BeadChip panel and later (11th to 25th year) using a BovineLD BeadChip (6 K) panel for posterior genotype imputation, once the utilization of this panel leads to a genomic prediction reduction cost and a small accuracy loss (Segelke et al. 2012).

Feeding costs were obtained by expenses with silage, concentrate, minerals, pasture formation and maintenance for rearing females and dry cow's maintenance. To calculate feeding costs it was supposed that milking cows were kept confined in a free-stall system eating a diet with corn silage and grains (energy and protein), minerals and vitamins, with $40 \%$ concentrate. It was assumed a daily individual consumption of $1 \mathrm{~kg}$ of concentrate per $3 \mathrm{~kg}$ of milk produced, according with the amount of milk registered on control. It was also assumed that cows were milked three times a day, using a milk machine without the calf presence. Milk production was measured monthly.

Daily energy requirements for maintenance, growth, gestation and milk production corrected for $4 \%$ of fat were calculated to fulfill NRC (1989) recommendations. Based on feeding management and the estimation of daily net energy requirements (Mcal), it was possible to calculate milking cows feeding costs. Later this cost was multiplied by 305 lactation days and by the total number of milking cows to obtain the total feed cost. Considering NRC (1989) recommendations and the same procedure described above, it was possible to obtain feeding cost for others animals (calves, heifers, dry cows and bulls), including sires and dams rearing costs.

Food bromatological composition (dry matter (\%), crude protein $(\%)$ and total digestible nutrients (\%) used (Table 3) were obtained from Valadares Filho (2000).

Besides animal feeding costs, it was also considered costs with employees, taxes, fuel, hygiene material, energy, medication and reproduction, technical assistance and maintenance of infrastructure and equipment.

It was considered as income: the sale of milk and animals: discard cows (voluntary and involuntary), surplus heifers and calves (males and females). In order to obtain annual milk sales revenue, the average daily yields were multiplied by the number of lactating cows for $365 d$ and then by the amount paid per liter of milk. The voluntary and involuntary discard cows were classified as fat, with a carcass weight equivalent to $255 \mathrm{~kg}$. The venal value of heifers, female calves and male calves respectively corresponded to $0 \cdot 7$; 0.3 and $0.025 \%$ of a lactating cow average value (Table 2). Bulls were considered having the same price as the lactating cows.

The strategies were repeated 5 times for the comparison of changes in average EBVs and inbreeding coefficients over 25 years. The annual phenotypic means necessary to obtain the costs and revenues were calculated by multiplying the average EBVs by the phenotypic standard deviation

Table 3. Food composition (\%)

Food

Concentrate

Corn Silage

P. maximum Jacq. cv. Colonião

\begin{tabular}{rrr}
\multicolumn{1}{ll}{ DM } & CP & TDN \\
88.002 & $20 \cdot 002$ & $72 \cdot 302$ \\
0.307 & 6.730 & $63 \cdot 030$ \\
0.287 & 6.590 & 43.330
\end{tabular}

DM

DM, dry matter; CP, Crude protein; TDN, Total digestive nutrients. Valadares Filho (2000).

for milk production at $305 \mathrm{~d}$ of lactation for Holstein animals in Brazil (Andreazza et al. 2008) and later the traits phenotypic means were added (Table 1 ).

Subsequently, the discount on costs and benefits future was applied, so that the comparison between the strategies was fair, since the application of the financial resources and the obtaining of the benefits do not occur simultaneously. Thus, the results were expressed in comparable units of time, by the present value of costs and benefits, as described by Huirne \& Dijkhuizen (1997). The discount rate practiced was equal to the real interest rate paid by the average Brazilian savings account, which in the year 2013 was equal to $6 \cdot 32 \%$ per year (BACEN, 2013). After the discounts were applied, the viability indicators: net present value $(\mathrm{NPV})$, internal rate of return (IRR) and benefit-cost ratio $(B / C)$ were used in the process of choosing the best strategy.

\section{Results and discussion}

Changes in average true genetic values (TBV) due to the application of the different selection strategies are presented in Fig. 1. In the evaluation period, no relevant changes were observed in the average TBV(s) of the RS strategy animals, since the selection was based exclusively on random values. However, there were increases of $2.53 ; 4.20$ and 4.58 in the TBV(s) of the PS, Blup and GBlup/GBlupi strategies, respectively. Blup strategy presented a gain $66 \%$ higher than that observed for phenotypic selection. This result was similar to that observed by Seno et al. (2012), in which the authors demonstrated in dairy buffalo populations the importance of programs to control the performance and pedigree information associated with genetic evaluation in order to obtain greater genetic progress.

Genomic selection with panels of high (GBlup) and low (GBlupi) density showed increase of 81 and $9 \%$ in relation to PS and Blup, respectively. Despite the small advantage observed in relation to the Blup strategy, we consider this result to be consistent since, in order to make the study more realistic, we opted to start the process of genotyping of the animals in the $10^{\text {th }}$ year and, therefore, these strategies had only 15 consecutive years of genomic evaluation. In Fig. 1 , we can verify that up to the $17^{\text {th }}$ year the genomic selection strategies averages were practically equivalent and from the following year, these strategies began to present superior results in relation to BLUP.

The best performance observed in GBlup/GBlupi possibly occurred because these strategies rely on genetic evaluation 


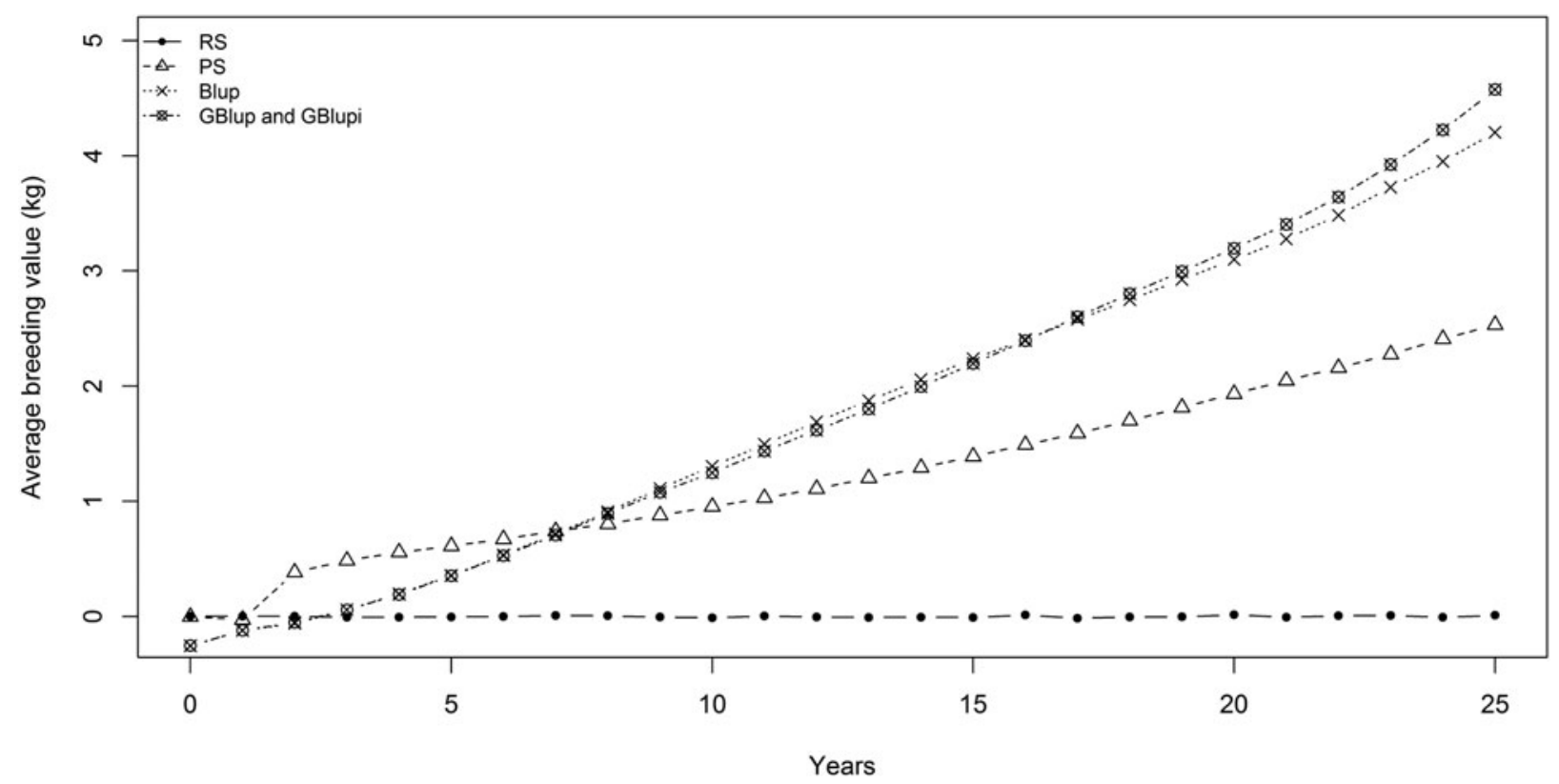

Fig. 1. True genetic value (TBV) observed in simulated dairy cattle populations after the application of different selection strategies, within a 25 year horizon of evaluation.

with sources of phenotypic information, genealogy, as well as genotypic data from molecular markers in linkage disequilibrium with genes of interest. While the traditional selection (Blup) relied only on the first two sources. It was not adopted a progeny test scheme, so that all strategies could be compared under the same conditions. Thus, we can credit the gain realized in genomic strategies to the best prediction of animal's genetic merit in the population. Schaeffer (2006) described in his study that the genetic change promoted by genomic selection may be up to three times that obtained in current progeny testing programs.

Average inbreeding coefficients (F) for RS, PS, Blup and GBlup/GBlupi strategies were 0.002; 0.007; 0.030 and $0 \cdot 027$, respectively, at the end of the 25-year evaluation (Fig. 2). The low value of $\mathrm{F}$ observed in the RS strategy $(0 \cdot 002)$ occurred because the animals selected for the next generation were less similar than the population mean, because the selection was based on random values. In addition, the bulls had the same probability of mating and the mating was assigned at random. These two factors also allowed the maintenance of the mean F in the PS strategy (0.007). Such assumptions differ from traditional selection a program that aims the intensive use of animals with high genetic values and this tends to increase the genetic links and consequently the inbreeding.

For Blup (0.030) and GBlup/GBlupi (0.027) strategies, we observed more realistic values even assuming the presuppositions mentioned above (Fig. 2). BLUP methodology provided greater precision in these strategies, which guaranteed higher rates of gain (Fig. 1), still observed inbreeding was also greater than phenotypic and random selection strategies. These results were similar to those presented by Quinton et al. (1992).

GBlup/GBlupi strategies presented an average inbreeding coefficient 10\% lower than observed in Blup (Fig. 2) after 25 years of evaluation. The reduction in the mean $\mathrm{F}$, in relation to the Blup methodology, can be noticed since the $10^{\text {th }}$ year of the selection program, the year in which the genomic information was included in the analysis. According to Daetwyler et al. (2007), the main reason for $\mathrm{F}$ reduction is that genomic selection results in an increase in the estimated accuracy of the Mendelian segregation term. This allows a better differentiation within the families and smaller coselection of siblings, which reduces F. According to these authors, in genomic selection the portion of the additive variance between families is reduced rapidly due to the high accuracy of the estimated genetic values and changes the emphasis of selection in favour of the term of the Mendelian segregation that has no effect on inbreeding.

To make the study more realistic, the costs and revenues of a simulated Holstein breed population were estimated. Feeding costs represented an average of $0.44 ; 0.47 ; 0.48$; 0.48 and $0.48 \%$ for the RS, PS, Blup and GBlup/GBlupi strategies, respectively. Labour costs were the second largest source of expenditure in the production system, with a mean of 0.41 being observed, respectively; $0.37 ; 0.36$; $0 \cdot 36$ and $0.36 \%$ for RS, PS, Blup and GBlup/GBlupi. There was an increase in food expenses and labor-related expenditure reduction due to the introduction of zootechnical control and genetic evaluation, either traditional or with the aid of genomic information. The intensification of the system provided an increase in the average production, by means of the average genetic gain (Fig. 1) and this gain 


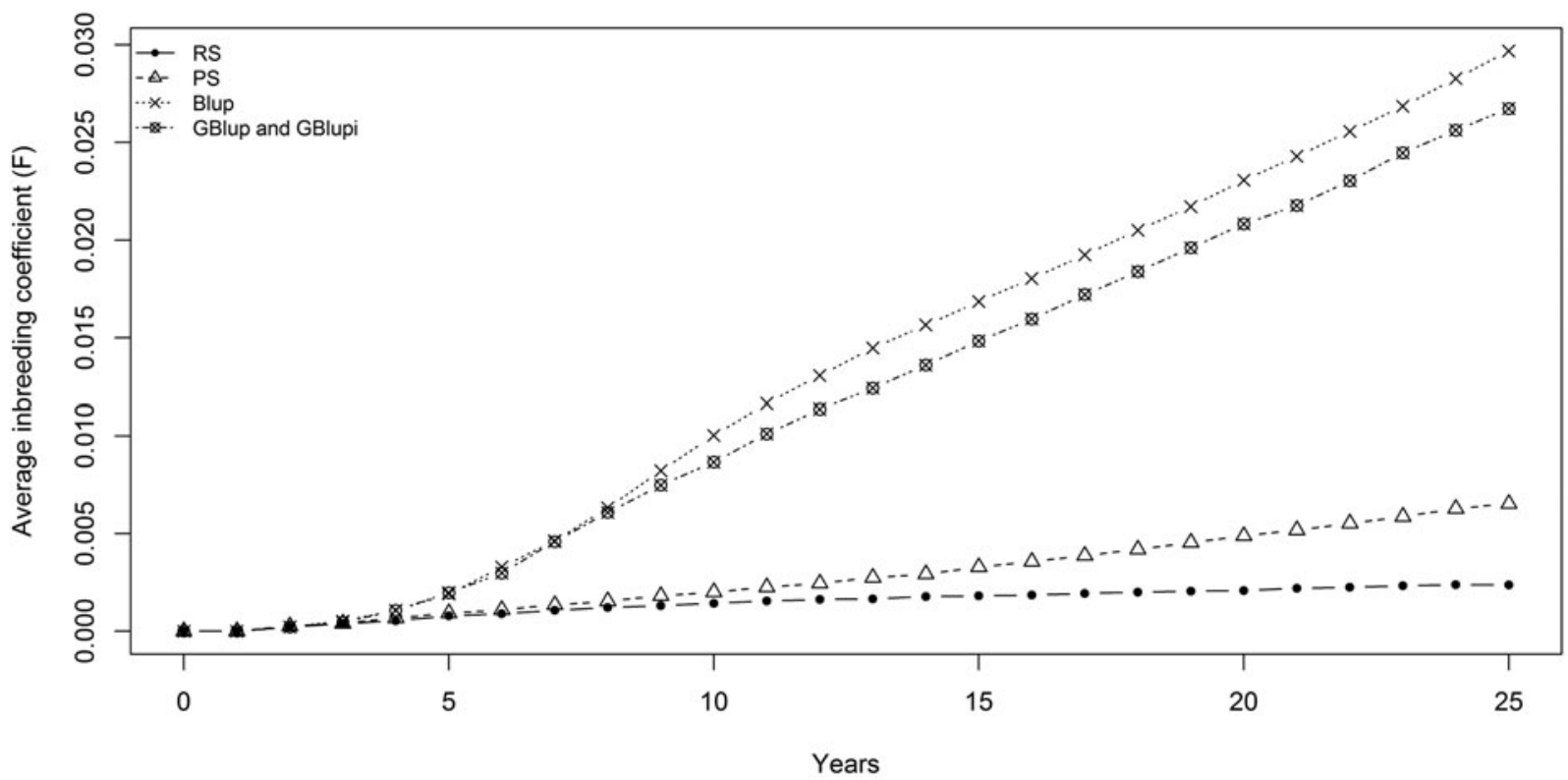

Fig. 2. Mean inbreeding coefficients $(\mathrm{F})$ observed in simulated dairy cattle populations after the application of different selection strategies, within a 25 year horizon of evaluation.

led to an increase in the nutritional requirement of the animals, heightening expenses. On the other hand, as the size of the population was fixed, and there was no need to increase the number of employees, labour costs were inversely proportional to the intensification, making the system more efficient.

The expenditures with zootechnical control and genetic evaluation represented $0.0 ; 0.007 ; 0.008 ; 0.008$ and $0.008 \%$ of the total production costs in the RS, PS, Blup and GBlup/GBlupi strategies, respectively. It should be noted that in the RS strategy, it was not considered the control and maintenance of zootechnical and pedigree information. Expenses with control and maintenance of this information in PS were only $12.5 \%$ lower than those observed in Blup and GBlup/GBlupi. A well planned breeding program may allow a perfect selection of animals, but an enterprise of this magnitude is expensive for some traits (eg milk quality traits) and beyond that it would be necessary a long wait to obtain the desired benefits. However, based on the genetic gains achieved observed in Blup and GBlup/ GBlupi (Fig. 1) we can clearly observe the benefits of genetic evaluation against phenotypic selection.

In GBlup and GBlupi, genotyping costs were US \$3.1 million and US $\$ 1.9$ million, respectively, and these values represented, respectively, 0.12 and $0 \cdot 08 \%$ of total production costs, which were around $\$ 2 \cdot 3$ billion in both cases over the last 25 years. Despite the small number of genotyped animals (3008 bulls and 15000 females), it is said that the amount of capital to be invested by the rural producer is high. However, when we look at the investment in animal genotyping as part of the dairy livestock enterprise, we can see that such an investment seems derisory.
Milk sales represented on average $80.9 ; 83.39 ; 84.12$; 84.15 and $84.15 \%$ of total revenues for the RS, PS, Blup and GBlup/GBlupi strategies, respectively. These results demonstrate once again that the intensification of the system improved the average productivity, through genetic progress (Fig. 1), guaranteeing an evolution of average annual income of rural producers.

For RS and PS strategies, negative net present values (NPV) of -164 and -31 million Dollars, respectively (Fig. 3) were found. These results indicate that the benefits obtained with the application of RS and PS strategies were insufficient to recover implementation costs, that is, these strategies are economically infeasible. On the other hand, the Blup and GBlup/GBlupi strategies presented positive NPV of 20, 21 and 22 million Dollars, respectively, indicating that they are economically viable (Fig. 3). Although the results are positive and indicate the feasibility of the application of resources, we must point out that the NPV indicates only the scale of the net benefits, but does not show the relative size of the benefits and costs of the enterprise (Huirne \& Dijkhuizen, 1997).

The internal rates of return (IRR) obtained with the application of RS and PS strategies were 1.58 and 5.60, respectively (Fig. 3).

Both values lower than the real interest rate paid by the savings account, which in the year 2013 was equal to $6 \cdot 32 \%$ pa (BACEN, 2013). These results indicate that it would be more advantageous for entrepreneurs to apply the resources in the savings account instead of executing the RS and PS strategies.

For Blup and GBlup/GBlupi strategies, were observed IRRs of $6.74 ; 6.76$ and 6.77 , respectively (Fig. 3). These results 

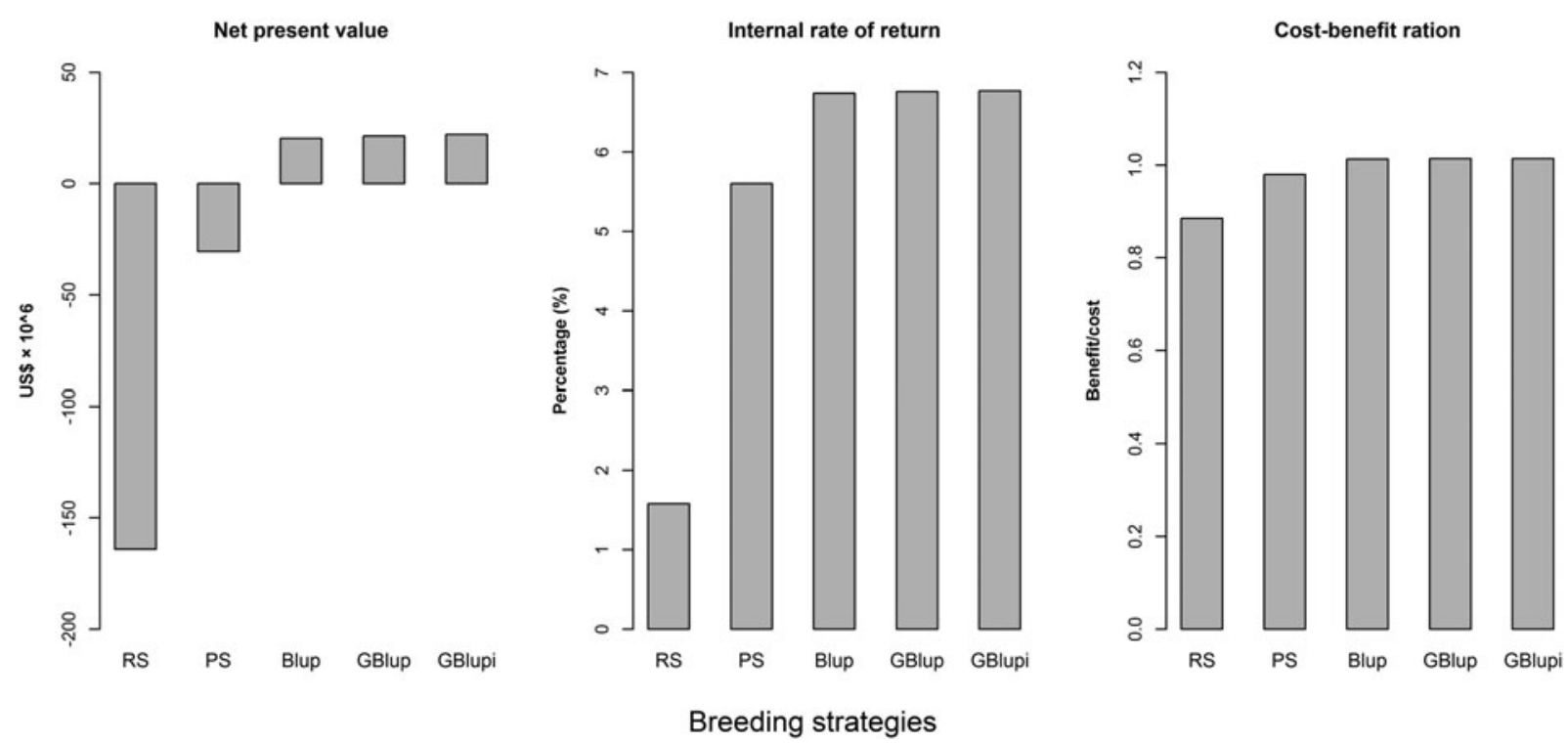

Fig. 3. Economic feasibility indicators used to evaluate the application of different strategies in simulated populations of dairy cattle.

indicate that all the strategies that contemplated zootechnical control in conjunction with genetic evaluation, even those that counted on the aid of genomic information, presented IRR higher than the interest paid by the savings account. Although small, an economic advantage can be observed for the execution of genomic selection strategies (GBlup/ GBlupi) against traditional selection. Even considering a small number of animals genotyped and starting the process of genotyping and selection from the $10^{\text {th }}$ year, both strategies provided greater genetic gain, which guaranteed the feasibility of the application of resources even with additional cost for the application of this biotechnology in practice.

The RS and PS strategies were also not feasible according to the $\mathrm{B} / \mathrm{C}$ ratio analysis, where they presented, respectively, values of 0.885 and 0.980 , that is, indicating that the discounted inflow was lower than the discounted flow of outputs. On the other hand, Blup and GBlup/GBlupi presented a $\mathrm{B} / \mathrm{C}$ ratio higher than 1 , signaling that the execution of these selection strategies would be viable. The observed ratios for these strategies were $1.013 ; 1.014$ and 1.014 , respectively.

\section{Conclusions}

Genetic evaluation with the aid of genomic information may improve the genetic gain rate in dairy breeding programs, as well as lower the average inbreeding coefficient.

Economic viability indicators showed that only Blup and GBlup/GBlupi strategies, those that had zootechnical control and genetic evaluation, either traditional or with the aid of genomic information, were economically viable considering a discount rate of $6,32 \%$ aa. However, it should be noted that the volume of investment to be applied and the maintenance of such a venture is very high.
Financial support from CAPES Process number 23038.000928/ 2010-42 is acknowledged.

\section{References}

Aguilar I, Misztal I, Johnson DL, Legarra A, Tsuruta S, Lawlor TJ 2010 A unified approach to utilize phenotypic, full pedigree, and genomic information for genetic evaluation of Holstein final score. Journal Dairy Science 93 743-752

Andreazza J, Rorato PRN, El Faro L, Boligon AA, Weber T, Kippert CJ, Lopes JS 2008 Parâmetros genéticos e eficiência relativa de seleção para a produção de leite no dia do controle para vacas da raça Holandesa. Ciência Rural 38(2) 451-456

ANUALPEC 2013 Anuário da Pecuária Brasileira. São Paulo: FNP Consultoria e Comércio

APCBRH/UFPR 2013 Associação Paranaense de criadores de bovinos da raça Holandesa Programa de análise de rebanhos leiteiros do Paraná. Disponível em: http://www.holandesparana.com.br/controle/parlpr.html. Acesso em: 11 nov 2013

BACEN 2013 Banco Central do Brasil. Captação em depósitos de poupança - dados mensais. Disponível em: http://www.bcb.gov.br/. Acesso em: 11 nov 2013

Barbosa Silveira ID, Peters MDP, Storch T, Ziguer EA, Fisher V 2011 Simulação da rentabilidade e viabilidade econômica de um modelo de produção de leite em free-stall. Arquivo Brasileiro de Medicina Veterinária e Zootecnia, Belo Horizonte 63(2) 392-398

Boligon AA, Long N, Albuquerque LG, Weigel KA, Gianola D, Rosa GJM 2012 Comparison of selective genotyping strategies for prediction of breeding values in a population undergoing selection. Journal of Animal Science 90 4716-4722

Cardoso VL, Cassoli LD, Guilhermino MM, Machado PF, Nogueira JR, Freitas MAR 2005 Análise econômica de esquemas alternativos de controle leiteiro. Arquivo Brasileiro de Medicina Veterinária e Zootecnia, Belo Horizonte 57(1) 85-92

Christensen O, Lund M 2010 Genomic prediction when some animals are not genotyped. Genetics Selection Evolution 422

Chud TCS, Ventura RV, Schenkel FS, Carvalheiro R, Buzanskas ME, Rosa JO Mudadu MA, da Silva MVGB, Mokry FB, Marcondes CR, Regitano LCA, Munari DP 2015 Strategies for genotype imputation in composite beef cattle. BMC Genetics 16 99. DOI: 10.1186/s12863-015-0251-7 
Daetwyler HD, Villanueva B, Bijma P, Woolliams JA 2007 Inbreeding in genome-wide selection. Journal of Animal Breeding and Genetics 124 369-376

De Roos APW, Schrooten C, Mullaart E, Calus MPL, Veerkamp RF 2007 Breeding value estimation for fat percentage using dense markers on Bos Taurus autosome 14. Journal Dairy Science 90 4821-4829

DEOXI 2013 Deoxi Biotecnologia Ltda. Biotecnologia Aplicada ao Agronegócio. Disponível em: www.deoxi.com.br. Acesso em: 11 nov

Garrick DJ 2011 The nature, scope and impact of genomic prediction in beef cattle in the United States. Genetics, Selection, Evolution 43(1) 17. 10.1186/1297-9686-43-17

Gengler N, Mayeres P, Szydalowski M 2007 A simple method to approximate gene content in large pedigree populations: application to the myostatin gene in dual-purpose Belgian blue cattle. Animal 1 21-28

GESTOR LEITE 2013 Gestor Leite - CRV Lagoa Ltda. Programa de melhoramento genético em leite da CRV Lagoa. Disponível em: www.crvlagoa. com.br/gestorleite.asp. Acesso em: 11 nov 2013

Harris BL, Johnson DL, Spelman RJ 2008 Genomic selection in New Zealand and the implications for national genetic evaluation. Proceedings of the Interbull Meeting, Niagara Falls, NY

Hayes B, Goddard ME 2001 The distribution of the effects of genes affecting quantitative traits in livestock. Genetics Selection Evolution 33(3) 209229

Hayes BJ, Bowman PJ, Chamberlain AJ, Goddard ME 2009 Invited review: genomic selection in dairy cattle: progress and challenges. Journal Dairy Science 92 433-444

Huirne RBM, Dijkhuizen AA 1997 Basic methods of economic analysis. In Animal Health Economics: Principles and Applications, pp. 25-39 (Eds AA Dijkhuizen, RS Morris). Sydney: University of Sydney, cap. 03

IEA 2013 Instituto de Economia Agrícola. Banco de dados: preços médios mensais pagos pela agricultura. Disponível em: http://www.iea.sp.br. Acesso em: 11 nov 2013

Jiménez-Montero JA, González-Recio O, Alenda R 2012 Genotyping strategies for genomic selection in small dairy cattle populations. Animal 6(8) 1216-1224

Legarra A, Aguilar I, Misztal I 2009 A relationship matrix including full pedigree and genomic information. Journal Dairy Science 92, 4656-4663
Misztal I, Legarra A, Aguilar I 2009 Computing procedures for genetic evaluation including phenotypic, full pedigree and genomic information. Journal Dairy Science 92 4648-4655

NRC 1989 Nutrient Requeriments of Dairy Cattle, 157p, 6th rev edition. Washinton, DC: National Research Council

Pszczola M, Mulder HA, Calus MP 2011 Effect of enlarging the reference population with (un)genotyped animals on the accuracy of genomic selection in dairy cattle. Journal Dairy Science 94 431-441

Quinton M, Smith C, Goddard ME 1992 Comparison of selection methods at the same level of inbreeding. Journal of Animal Science 70(4) 10601067. doi: 10.2527/1992.7041060x

Resende MDV, Lopes PS, Silva RL, Pires IE 2008 Seleção genômica ampla (GWS) e maximização da eficiência do melhoramento genético. Pesquisa florestal brasileira 56 63-77

Sargolzaei M, Schenkel FS 2009 QMSim: a large-scale genome simulator for livestock. Bioinformatics 25 680-681

Sargolzaei M, Schenkel FS, Jansen GB, Schaeffer LR 2008 Extent of linkage disequilibrium in Holstein cattle in North America. Journal Dairy Science 91 2106-2117. doi: 10.3168/jds.2007-0553

Schaeffer LR 2006 Strategy for applying genome-wide selection in dairy cattle. Journal of Animal Breeding and Genetics 123 218-223. doi: 10.1111/j.1439-0388.2006.00595.x

Segelke D, Chen J, Liu Z, Reinhardt F, Thaller G, Reents R 2012 Reliability of genomic prediction for German Holsteins using imputed genotypes from low-density chips. Journal Dairy Science 95(9) 5403-5411. doi: 10.3168/jds.2012-5466

Seno LO, Fernández J, Cardoso VL, García-Cortes LA, Toro M, Santos DO, Albuquerque LG, de Camargo GMF, Tonhati H 2012 Selection strategies for dairy buffaloes: economic and genetic consequences. Journal of Animal Science 129 1-13, doi: 10.1111/j.1439-0388.2012.00992.x

Valadares Filho SC 2000 Nutrição, avaliação de alimentos e tabelas de composição de alimentos. In REUNIÃO ANUAL DA SOCIEDADE BRASILEIRA DE ZOOTECNIA, pp. 267-340 37, 2000, Viçosa, MG Anais... Viçosa, MG: Sociedade Brasileira de Zootecnia

VanRaden PM, VanTassell CP, Wiggans GR, Sonstegard TS, Schnabel RD, Taylor JF, Schenkel FS 2009 Invited review: reliability of genomic predictions for North American Holstein bulls. Journal Dairy Science 92 16-24 
Copyright (C) Hannah Dairy Research Foundation 2018 